Research Article

\title{
Technological Learning and Technological Innovation Creation: An Empirical Analysis of Biotechnology R\&D Teams
}

\author{
Hao-Chen Huang \\ Department of Wealth and Taxation Management, National Kaohsiung University of Applied Sciences, Taiwan, R.O.C. \\ E-mail: haochen@kuas.edu.tw
}

Received 15 May 2013; Accepted 25 July 2013

\begin{abstract}
Resource-based perspective was used to relate the technological learning processes and transformative capacity to technological innovation using a sample of 193 biotechnology R\&D teams. Structural equation modeling was used to conduct confirmatory factor analysis (CFA) to evaluate the measurement model, while hierarchical regression analysis was used to test the hypotheses. As expected, the technological learning processes were positively associated with technological innovation. Further, the transformative capacity of R\&D team was also crucial. The transformative capacity is a powerful approach to maintaining, transforming, and reactivating knowledge for biotechnology firms. It positively moderated the association between external learning and technological innovation.
\end{abstract}

Keywords: External learning, Internal learning, Transformative capacity

\section{Introduction}

From the resource-based perspective, technological learning is regarded as a firm's core competence $[1,2,3]$ through which firms can develop technological knowledge and capability [4]. Accordingly, technology learning is the process by which firms can acquire external technology and accumulate technology capabilities intended to improve their competitive advantage [5]. In addition, from the resource dependency perspective, firms are not completely independent; they often need other organizations or firms to offer them necessary resources and aids. If an organization wants to increase its innovation capability, it would need to integrate exterior knowledge [6]. Thus, successful firms can accumulate competence through internal technological learning after transferring technologies from external technology sources [7]. In theory, internal technological knowledge and capability would help increase or enhance technological innovation and firm performance through the internal learning processes. However, in reality, firms require both internal and external technological knowledge and capabilities to strengthen technological innovation and achieve maximum firm performance, especially in emerging industries. Reliance on external sources of knowledge and research skills is often considerable, as seen in the development of biotechnology firms. Biotechnology is now recognized as one of the most important and significant industries worldwide [8]. In Taiwan, biotechnology is also one of the fastest growing industries with vast potential [9]. The biotechnology industry is knowledge-intensive, thus, firm capacity for technological innovation becomes a key

* E-mail address: haochen@kuas.edu.tw

ISSN: 1791-2377 @ 2013 Kavala Institute of Technology. All rights reserved. source of competitive advantage. Biotechnological organizations rely heavily on technological innovation whilst technological learning is crucial in such organizations.

Prior work on technological innovation enhancement were mostly concentrated on firms' in-house R\&D capabilities [10] and rarely focused on the impact of external forces [11]. Few studies have simultaneously examined the relationships between both the external and internal learning process and performance [12], though the influence of external and internal learning on performance has been noted in earlier researches [13]. Hence, this study attempts to fill the research gap by investigating how biotechnology firms use their transformative capacity to foster technological innovation from the resource-based perspective and to explore the influence of technological learning processes on technological innovation.

\section{Theory and Hypotheses}

\subsection{Technological Learning and Technological Innovation}

In previous studies, technological learning was separated into two types: internal learning and external learning [12]. Accordingly, internal learning is defined as organizational members' acquirement of new information and knowledge by exchanging it with and transferring it to and from other organization units or members. On the other hand, external learning is defined as organizational members' acquirement of new information and knowledge by interacting and cooperating with other organizations. Technological learning is the process through which a member obtains new information or knowledge. Similarly, technological learning 
is regarded as the process by which a technology-driven firm creates, renews, and upgrades its latent and currently used capabilities based on its stock of explicit and tacit resources [14]. Moreover, technological learning is also the knowledge management process that aids people in decision-making, increases organizational effectiveness and facilitates capability improvements.

In a knowledge-intensive industry such as biotechnology, technological innovation is critical to any organization's ability to develop new products and enhance firm performance. In prior research, technological innovation has been suggested as a useful tool for corporate strategy [15]. For example, Bessant [16] suggested that technological innovation represents an important mechanism by which firms could respond to the environmental challenges in the late 1990s. Additionally, Capaldo et al. [17] defined the degree of technological innovation capability as a firm's degree of capability to increase its technological know-how and expertise in a given moment in time. Finally, Bao [18] defined technological innovation as new knowledge or know-how employed to develop or manufacture a product or service. In accordance with prior studies, technological innovation is defined as an organisation's ability to enhance its technological innovativeness and create new customer value propositions by offering new products and services, adopting new technologies, or creating new skills and competencies [11].

Cohen and Levinthal [19] suggested that $R \& D$ is insufficient as an internal learning indicator and that the internal learning is also the foundation of effective external learning because a firm has to build a sufficient internal knowledge base to understand, interpret and use external knowledge effectively. Furthermore, Schroeder et al. [13] suggested that resources and capabilities are formed by employees' internal learning based on cross-training and suggestion systems, external learning from customers and suppliers, and proprietary processes and equipment developed by the firm. With the aim of building and reinforcing organizational competitive advantage, de Pablos [20] suggested knowledge from both internal learning (investment in R\&D) and external learning (learning from an alliance partner, competitor, etc.) has become a strategic process that contributes to the acquisition and deployment of the organizational knowledge stock and flow. Stock et al. [21] suggested that technological innovation can be thought of as the incorporation of technology into the development of new products or processes. Therefore, to enhance technological innovation, firms must acquire both external and internal technological knowledge. Thus, technological learning may be an appropriate method of strengthening technological innovation capabilities. For example, Hull and Covin [22] suggested that a firm's internal ability to innovate, as reflected in its learning capability, has relevance far beyond the firm's likely internal innovation output. Bierly III et al. [23] suggested that the transfer and use of knowledge from external sources expands a firm's knowledge base and provides access to new ideas that promote the generation of new products and technology. Tsai and Wang [24] suggested that firms can improve their technological innovation by collaborating with competent competitors, thereby simultaneously accelerating their capability development and reducing technological innovation time. In addition, to remain as the technological avant-garde, Figueiredo [25] suggested that firms must engage in technological learning processes to build up their ability to carry out innovative activities independently. Most prior studies have agreed on the mutual relationship between technological learning processes and innovation. In summary, an effective technological learning process is the key factor that facilitates a firm's ability to acquire technological knowledge and improve technological innovation. Therefore, the following hypotheses inspired by previous studies are presented:

H1: External learning is positively related to technological innovation.

H2: Internal learning is positively related to technological innovation.

\subsection{Moderating Effects of Transformative Capacity}

First described by Cohen and Levinthal [19], absorptive capacity is defined as the firm's ability to explore, transform, and exploit knowledge, which may determine its level of organizational innovation and competence $[19,26]$. Intended to complement the concept of absorptive capacity, transformative capacity is a term that was coined by Garud and Nayyar [27], who defined transformative capacity as the ability to continually redefine a product portfolio based on the technological opportunities created within a firm. Similarly, Lichtenthaler and Lichtenthaler [28] defined transformative capacity as a firm's ability to retain knowledge inside the organization. Firms acquire new information and technological knowledge through technological learning processes. To successfully strengthen technological innovation, firms must actively maintain assimilated technological knowledge and reactivate this knowledge. Accordingly, the ability of a firm to develop its transformative capacity should grow as staff members become able to store vital knowledge in a knowledge management system and the system allows them to identify the existence of stored knowledge and retrieve it [29].

Previous research in this field has concentrated on the development of transformative capacity, its influence and the relationship between transformative capacity and innovation creation [26, 29]. Traditionally, firms build their learning resources through externally focused activities and sources such as cooperative partners, customers, suppliers, benchmarking, technology-brokering, and environmental scanning, along with internally focused systems such as cross-training, Intranets, firm-wide databases, and crossfunctional teams designed to facilitate information exchange and knowledge management across organizational levels and units [13]. A firm's transformative capacity helps a firm to link external and internal technology sourcing and thereby benefit from that technology acquisition. Thus, firms can maintain and reactivate their technological knowledge by developing transformative capacity. When a firm possesses an adequate level of transformative capacity, it tends to strengthen its level of technological innovation by combining external and internal sources of knowledge. Consequently, this work formulates the following hypotheses:

H3a: Transformative capacity positively moderates the relationship between external learning and technological innovation.

H3b: Transformative capacity positively moderates the relationship between internal learning and technological innovation.

The conceptual framework implied by our hypotheses is shown in Figure 1. The conceptual model shows how internal and external learning are antecedents of technological innovation (H1, H2). Followed by that, transformative capacity plays a moderating role in the 
relationship between external learning and technological innovation ( $\mathrm{H} 3 \mathrm{a})$ and in that between internal learning and technological innovation (H3b).

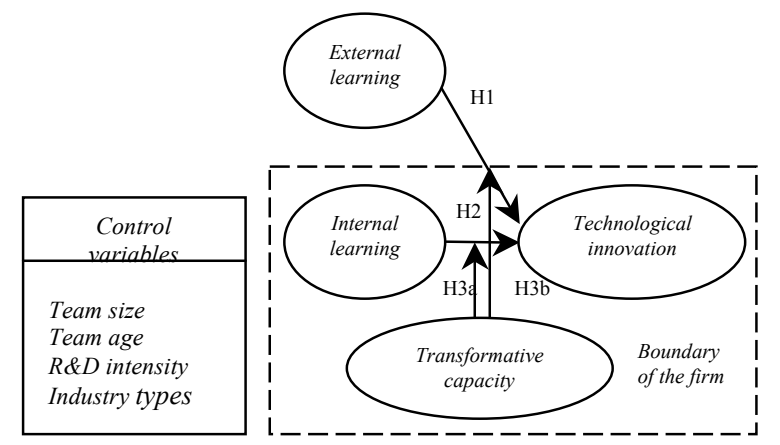

Fig. 1. Conceptual framework

\section{Methods}

\subsection{Sample and Procedure}

Taiwanese biotechnology-related applications can be classified into three basic categories: emerging biotechnology, pharmaceutical and medical device. A questionnaire survey with closed structured questions was used as the main method of data collection. In the pre-test stage, this study selected 30 biotechnology R\&D teams. The questionnaires and introduction letters were sent to $R \& D$ manager via mail or email. The results show that each construct's Cronbach $\alpha$ was higher than 0.8 and that all items should be appropriate for subsequent surveys. This study also conducted field interviews with some R\&D managers, asking them a series of open-ended questions regarding the technological learning processes and transformative capacity of the biotechnology $R \& D$ teams. After face-to-face interviews with the $\mathrm{R} \& \mathrm{D}$ managers, the survey was then conducted.

The survey was conducted in two waves. Three weeks after the first mailing of the questionnaires and introductory letters, reminder letters and questionnaires were sent out to non-respondents. A telephone survey was used as a supplementary tool to boost the response rate. As a result, this study collected 200 copies of surveys. Of these 200 questionnaires returned, only 193 were usable. Non-response bias was assessed via a comparison between first-wave (early respondent) and second-wave (late respondent) data [30]. Following the procedure suggested by Armstrong and Overton [30], $t$-tests were performed comparing early and late respondents with regard to key characteristics such as firm size and annual sales. No significant differences were found between early and late respondents in terms of firm size or annual sales at the $5 \%$ confidence level.

\subsection{Measures}

Each indicator was measured on a 5-point Likert scale ranging from 5 "strongly agree" to 1 "strongly disagree".

External learning (EL): External learning is defined as organizational members' acquiring new information and knowledge by interacting and cooperating with other organizations. A four-item measure of external learning modified from Schroeder et al. [13] is used: (a) Our team always strives to establish long-term relationships with suppliers.

Internal learning (IL): Internal learning is defined as organization members' acquiring new information and knowledge by exchanging it with and transferring it among other units or members within that organization. A four-item measure of internal learning is modified from Huang [11] and Schroeder et al. [13] and used: (a) Our team members always acquire new knowledge and information through cross-training at this plant.

Technological innovation (TI): Technological innovation is defined as a firm's ability to create new customer value propositions by offering new products and services, adopting new technologies, or creating new skills and competencies. A four-item measure of technological innovation is modified from Huang, Lai and Lo [31] and Perdomo-Ortiz et al. [32] and used: (a) Our team members always possess excellent technological options for new product development projects.

Transformative capacity (TC): This study defines transformative capacity as the ability to maintain, transform, and reactivate knowledge, which may determine organizational innovation and competence levels [26, 27]. To examine transformative capacity, a four-item measure of transformative capacity is modified from Lichtenthaler [26] and used: (a) Our team always has the ability to store knowledge and information from external sources and channels.

Control variables: Two variables related to team composition: team size, the natural $\log$ of the number of members that were on the team, and team age, the natural $\log$ of the number of years since the team was founded, were assessed. At the firm level, this study controlled the R\&D intensity [33]. At the industry level, this study controlled the effects of industry types [34].

\section{Empirical Results}

\subsection{Descriptive Statistics}

Table 1 summarizes the descriptive statistics and the Pearson correlation coefficients for measurement variables in this work. A post hoc analysis using Harman's one-factor test indicates that not all variables load onto a common factor, which suggests that common method variance is not the primary determinant of the results in this study [35].

\begin{tabular}{|c|c|c|c|c|c|c|c|c|c|}
\hline & 1 & 2 & 3 & 4 & 5 & 6 & 7 & 8 & 9 \\
\hline 1.Team size & 1 & & & & & & & & \\
\hline 2.Team age & .013 & 1 & & & & & & & \\
\hline 3.R\&D intensity & $.510^{* *}$ & -.022 & 1 & & & & & & \\
\hline $\begin{array}{l}\text { 4.Emerging } \\
\text { biotechnology } \\
\text { industry }\end{array}$ & -.080 & .058 & -.039 & 1 & & & & & \\
\hline $\begin{array}{l}\text { 5.Pharmaceutical } \\
\text { industry }\end{array}$ & $.219^{* *}$ & .062 & .023 & $.509^{-} *$ & 1 & & & & \\
\hline $\begin{array}{l}\text { 6.External } \\
\text { learning }\end{array}$ & $.213^{* *}$ & .109 & .131 & $-.162^{*}$ & $.166^{*}$ & 1 & & & \\
\hline $\begin{array}{l}\text { 7.Internal } \\
\text { learning }\end{array}$ & $.228^{* *}$ & .008 & $.213^{* *}$ & .011 & $.171^{*}$ & $.558^{* *}$ & 1 & & \\
\hline $\begin{array}{l}\text { 8.Transformative } \\
\text { capacity }\end{array}$ & $.293^{* *}$ & .034 & $.194^{* *}$ & -.085 & $.174^{*}$ & $.501 * *$ & $.532 * *$ & 1 & \\
\hline $\begin{array}{l}\text { 9. Technological } \\
\text { innovation }\end{array}$ & $.463 * *$ & .049 & $.403^{* *}$ & -.003 & .021 & $.433 * *$ & $.477 * *$ & $.584 * *$ & 1 \\
\hline Mean & 3.553 & 2.871 & .053 & .394 & .285 & 3.977 & 3.709 & 3.919 & 3.779 \\
\hline S.D. & .363 & .364 & .022 & .490 & .453 & .590 & .625 & .603 & .641 \\
\hline
\end{tabular}

\subsection{Confirmatory Factor Analysis (CFA)}

Table 2 shows the fitting index measurement for each construct. Convergent validity can be evaluated by considering both factor-loadings and t-values. All of the multi-item constructs fit this criterion, and the loadings are significantly related to the underlying factor (i.e., t-values are greater than 1.96), thus supporting convergent validity. 
The composite reliability (CR) and average variance extracted (AVE) measurements confirm the sample's reliability and convergent validity, with all reliability indices greater than 0.60 , and the average variance shared between the construct and the measures above 0.50 , as recommended by Bentler and $\mathrm{Wu}$ [36]. All four constructs had AVE exceeding 0.50 , indicating acceptable convergent validity.

Table 2. Individual item reliability, $\mathrm{CR}$ and AVE

\begin{tabular}{lccccc}
\hline \multicolumn{1}{c}{ Construct } & $\lambda$ & $\lambda^{2}$ & t-value & CR & AVE \\
\hline 1.External learning & $0.70-0.90$ & $0.49-0.81$ & $15.78-20.08$ & 0.88 & 0.66 \\
$\begin{array}{l}\text { 2.Internal learning } \\
\text { 3.Technological }\end{array}$ & $0.71-0.90$ & $0.50-0.81$ & $15.70-20.21$ & 0.89 & 0.67 \\
$\begin{array}{l}\text { innovation } \\
\text { 4.Transformative } \\
\text { capacity }\end{array}$ & $0.64-0.88$ & $0.41-0.77$ & $10.11-17.26$ & 0.83 & 0.62 \\
\hline
\end{tabular}

\subsection{Results of Hierarchical Regression Analysis}

To deal with multicollinearity problems, this study follows the procedures of Aiken and West [37] by subtracting the average from major variables and then centering them. However, the variance inflation factors (VIFs) of the contextual variables were all less than 10 , indicating that multicollinearity is not a problem [38]. Table 3 shows the effect of technological learning on technological innovation. In model 1 , control variables are introduced $\left(R^{2}=0.259\right.$, $\mathrm{p}<0.01)$. This study controlled team size, team age, R\&D intensity, and industry types in all models. In model 2, external learning and internal learning are introduced $\left(R^{2}=0.428, \mathrm{p}<0.01\right)$. Table 4 shows the moderating effect of transformative capacity on the relationship between technological learning processes and technological innovation. In Model 3, transformative capacity is brought in $\left(R^{2}=0.514, \mathrm{p}<0.01\right)$. Finally, in model 4 , the interaction between external learning and transformative capacity and the interaction between internal learning and transformative capacity are included $\left(R^{2}=0.552, \mathrm{p}<0.01\right)$. All four models are significant.

Table 3. The effect of technological learning on technological innovation

\begin{tabular}{|c|c|c|c|c|}
\hline & \multicolumn{4}{|c|}{ Technological innovation } \\
\hline & \multicolumn{2}{|c|}{ Model 1} & \multicolumn{2}{|c|}{ Model 2} \\
\hline & $\bar{\beta}$ & $t$ & $\beta$ & $t$ \\
\hline \multicolumn{5}{|l|}{ Control variables } \\
\hline Team size & $.366^{* *}$ & 4.840 & $.299 * *$ & 4.435 \\
\hline Team age & .053 & .839 & .033 & .585 \\
\hline$R \& D$ intensity & $.219^{* *}$ & 2.969 & $.167^{*}$ & 2.533 \\
\hline Emerging biotechnology industry & -.004 & -.051 & -.016 & -.240 \\
\hline Pharmaceutical industry & -.069 & -.916 & $-.141^{*}$ & -2.073 \\
\hline \multicolumn{5}{|l|}{ Independent variables } \\
\hline External learning $(\mathrm{H} 1)$ & & & $.208^{* *}$ & 2.983 \\
\hline Internal learning (H2) & & & $.281^{* *}$ & 4.013 \\
\hline$R^{2}$ & \multicolumn{2}{|c|}{.259} & \multicolumn{2}{|c|}{.428} \\
\hline Adjusted $R^{2}$ & \multicolumn{2}{|c|}{.239} & \multicolumn{2}{|c|}{.407} \\
\hline$R^{2}$ & \multicolumn{2}{|c|}{.259} & \multicolumn{2}{|c|}{.170} \\
\hline F-value & \multicolumn{2}{|c|}{$13.054 * *$} & \multicolumn{2}{|c|}{$19.797^{* *}$} \\
\hline F change & \multicolumn{2}{|c|}{$13.054^{* *}$} & \multicolumn{2}{|c|}{$27.430^{* *}$} \\
\hline
\end{tabular}

This study has also examined the differences in models by hierarchical regression. Model 1 serves as the base model for model 2, which in turn is the base for models 3 and 4 . Table 3 shows that $R^{2}$ increased significantly from model 1 to model 2 and that model 2 explains $42.8 \%$ of the total variance in business model innovation. Similarly, $R^{2}$ increased significantly from model 3 to model 4 and model 4 explains $55.2 \%$ of the total variance in technological innovation. In Model 4, H1 and $\mathrm{H} 2$ are both supported, which means that both external learning $(\beta=0.137, \mathrm{p}<0.05)$ and internal learning $(\beta=0.160, \mathrm{p}<0.05)$ are positively related to technological innovation. Moreover, the transformative capacity $(\beta=0.347, \quad \mathrm{p}<0.01)$ is positively related to technological innovation. Model 4 also demonstrates that $\mathrm{H} 3 \mathrm{a}$ is supported in that external learning $\times$ transformative capacity $(\beta=0.238, \quad \mathrm{p}<0.01) \quad$ is positively related to technological innovation. However, internal learning $\times$ transformative capacity $(\beta=-.065$, $\mathrm{t}$-value $=-1.001)$ is not. Hence, hypothesis $3 b$ is not supported. As for the control variables, team size and $R \& D$ intensity both have significant effects on technological innovation.

Table 4. The moderating role of transformative capacity

\begin{tabular}{|c|c|c|c|c|c|}
\hline & \multicolumn{5}{|c|}{ Technological innovation } \\
\hline & \multicolumn{2}{|c|}{ Model 3} & \multicolumn{2}{|c|}{ Model 4} & \multirow[b]{2}{*}{$V I F$} \\
\hline & $\bar{\beta}$ & $\bar{t}$ & $\beta$ & $t$ & \\
\hline \multicolumn{6}{|l|}{ Control variables } \\
\hline Team size & $.246^{* *}$ & 3.900 & $.241^{* *}$ & 3.965 & 1.505 \\
\hline Team age & .034 & .642 & .018 & .361 & 1.051 \\
\hline $\mathrm{R} \& \mathrm{D}$ intensity & $.163^{* *}$ & 2.675 & $.127^{*}$ & 2.130 & 1.438 \\
\hline $\begin{array}{l}\text { Emerging biotechnology } \\
\text { industry }\end{array}$ & -.010 & -.154 & -.048 & -.792 & 1.502 \\
\hline $\begin{array}{l}\text { Pharmaceutical industry } \\
\text { Independent variables }\end{array}$ & $-.152^{*}$ & -2.419 & $-.168^{* *}$ & -2.752 & 1.509 \\
\hline$\overline{\text { External learning }(\mathrm{H} 1)}$ & .108 & 1.618 & $.137^{*}$ & 2.095 & 1.735 \\
\hline Internal learning (H2) & $.155^{*}$ & 2.271 & $.160^{*}$ & 2.421 & 1.785 \\
\hline $\begin{array}{l}\text { Transformative capacity } \\
\text { Interacting variables }\end{array}$ & $.369^{* *}$ & 5.699 & $.347 * *$ & 5.517 & 1.608 \\
\hline $\begin{array}{l}\text { External learning } \times \\
\text { Transformative capacity (H3a) }\end{array}$ & & & $.238^{* *}$ & 3.597 & 1.772 \\
\hline $\begin{array}{l}\text { Internal learning } \times \\
\text { Transformative capacity }(\mathrm{H} 3 \mathrm{~b})\end{array}$ & & & -.065 & -1.001 & 1.703 \\
\hline$R^{2}$ & \multicolumn{2}{|c|}{.514} & \multicolumn{3}{|c|}{.552} \\
\hline Adjusted $R^{2}$ & \multicolumn{2}{|c|}{.493} & \multicolumn{3}{|c|}{.527} \\
\hline$R^{2}$ & \multicolumn{2}{|c|}{.086} & \multicolumn{3}{|c|}{.038} \\
\hline F-value & \multicolumn{2}{|c|}{$24.331^{* *}$} & \multicolumn{3}{|c|}{$22.426^{* *}$} \\
\hline F change & \multicolumn{2}{|c|}{$32.480^{* *}$} & \multicolumn{3}{|c|}{$7.709 * *$} \\
\hline
\end{tabular}

\section{Conclusion}

First, this study distinguishes between two constructs, external learning and internal learning, and then explores the relationship between these two constructs and their impact on technological innovation. As a result, among the variables derived from technological learning, external and internal learning positively affect technological innovation. In addition, this study determines whether or not transformative capacity moderates the relationship between external learning and technological innovation as well as whether it moderates the relationship between internal learning and technological innovation. The results of OLS analysis indicate that transformative capacity moderates the relationship between external learning and technological innovation. Specifically, the relationship between internal learning and technological innovation is stronger when R\&D team makes the most of transformative capacity. In other words, R\&D team employees who possess a high-level transformative capacity are more likely to exhibit higher technological innovation than those that do not. The findings of this study suggest that transformative capacity could complement the technological learning process and indeed enhance technological innovation.

Additionally, as proposed by Garud and Nayyar (1994), transformative capacity could make up for the inadequacy of absorptive capacity as transformative capacity is a powerful approach to maintain, transform, and reactivate knowledge for biotechnology firms. Consequently, biotechnology firms 
have become increasingly aware of the need to leverage transformative capacity to strengthen technological innovation. Management should thus spend time and energy on learning how to employ transformative capacity to achieve organizational competitive advantage.

\section{Acknowledgment}

The author would like to thank the National Science Council of the Republic of China, Taiwan for financially supporting this research under Contract No. 98-2410-H-151-010.

\section{References}

1. Bolivar-Ramos, M.T., Garcia-Morales, V.J., Garcia-Sanchez, E., "Technological distinctive competencies and organizational learning: Effects on organizational innovation to improve firm performance", Journal of Engineering and Technology Management, vol. 29 no. 3, pp. 331-357, 2012.

2. Garcia, F., Avella, L., Fernandez, E., "Learning from exporting: The moderating effect of technological capabilities", International Business Review, vol. 21 no. 6, pp. 1099-1111, 2012.

3. Ignatius, J., Leen, J.Y.A., Ramayah, T., Hin, C.K., Jantan, M., "The impact of technological learning on NPD outcomes: The moderating effect of project complexity", Technovation, vol. 32 no. 7-8, pp. 452-463, 2012

4. Hitt, M.A., Ireland, R.D., Lee, H.U., "Technological learning, knowledge management, firm growth and performance: An introductory essay", Journal of Engineering and Technology Management, vol. 17 no. 3-4, pp. 231-246, 2000.

5. Xie, W., "Technological learning in China's colour TV (CTV) industry", Technovation, vol. 24 no. 6, pp. 499-512, 2004.

6. Lorenzoni, G., Lipparini, A., "The leveraging of interfirm relationships as a distinctive capability: A longitudinal study", Strategic Management Journal, vol. 20 no. 4, pp. 317-338, 1999.

7. Lin, B.W., "Technology transfer as technological learning: A source of competitive advantage for firms with limited R\&D resources", R\&D Management, vol. 33 no. 3, pp. 327-341, 2003.

8. Nosella, A., Petroni, G., Verbano, C., "Characteristics of the Italian biotechnology industry and new business models: The initial results of an empirical study", Technovation, vol. 25 no.8, pp. 841-855, 2005.

9. Hsu, Y.G., Shyu, J.Z., Tzeng, G.H., "Policy tools on the formation of new biotechnology firms in Taiwan", Technovation, vol. 25 No. 3, pp. 281-292, 2005.

10. Vega-Jurado, J., Gutiérrez-Gracia, A., Fernández-de-Lucio, I., Manjarrés-Henríquez, L., "The effect of external and internal factors on firms' product innovation", Research Policy, vol. 37 no. 4, pp. 616-632, 2008.

11. Huang, H.C., "Technological innovation capability creation potential of open innovation: A cross-level analysis in the biotechnology industry", Technology Analysis \& Strategic Management, vol. 23 no. 1, pp. 49-63, 2011.

12. Bresman, H., "External learning activities and team performance: A multimethod field study", Organization Science, vol. 21 no. 1, pp. 81-96, 2010.

13. Schroeder, R., Bates, K., Juntilla, M.A., "A resource-based view of manufacturing strategy and the relationship to manufacturing performance", Strategic Management Journal, vol. 23 no. 2, pp. $105-17,2002$.

14. Carayannis, E.G., Popescu, D., Sipp, C., Stewart, M., "Technological learning for entrepreneurial development (TL4ED) in the knowledge economy (KE): Case studies and lessons learned", Technovation, vol. 26 no. 4, pp. 419-443, 2006.

15. Butler, J.E., "Theories of technological innovation as useful tools for corporate strategy", Strategic Management Journal, vol. 9 no. 1, pp. 15-29, 1988.

16. Bessant, J., "Developing technological capability through manufacturing strategy", International Journal of Technology Management, vol. 14 no. 2-4, pp. 177-195, 1997.

17. Capaldo, G., Iandoli, L., Raffa, M., Zollo, G., "The evaluation of innovation capabilities in small software firms: A methodological approach", Small Business Economics, vol. 21 no. 4, pp. 343-354, 2003.

18. Bao, Y., "Organizational resistance to performance-enhancing technological innovations: a motivation-threat-ability framework", The Journal of Business \& Industrial Marketing, vol. 24 no. 2, pp. $119-130,2009$.

19. Cohen, W., Levinthal, D., "Absorptive capacity: A new perspective on learning and innovation", Administrative Science Quarterly, vol. 35 no. 1, pp. 128-152, 1990.
20. De Pablos, P.O., "Knowledge management and organizational learning: Typologies of knowledge strategies in the Spanish manufacturing industry from 1995 to 1999”, Journal of Knowledge Management, vol. 6 no. 1, pp. 52-62, 2002.

21. Stock, G.N., Greis, N.P., Fischer, W.A., "Firm size and dynamic technological innovation", Technovation, vol. 22 no. 9, pp. 537549, 2002.

22. Bierly III, P.E., Damanpour, F., Santoro, M.D., "The application of external knowledge: Organizational conditions for exploration and exploitation", Journal of Management Studies, vol. 46 no. 3, pp. 481-509, 2009.

23. Tsai, K.H., Wang, J.C., "External technology sourcing and innovation performance in LMT sectors: An analysis based on the Taiwanese technological innovation survey", Research Policy, vol. 38 no. 3, pp. 518-526, 2009.

24. Figueiredo, P.N., "Learning, capability accumulation and firms differences: Evidence from latecomer steel", Industrial and Corporate Change, vol. 12 no. 3, pp. 607-643, 2003.

25. Lichtenthaler, U., "Absorptive capacity, environmental turbulence, and the complementarity of organizational learning processes", Academy of Management Journal, vol. 52 No. 4, pp. 822-846, 2009.

26. Garud, R., Nayyar, P.R., "Transformative capacity: Continual structure by intertemporal technology transfer", Strategic Management Journal, vol. 15 no. 5, pp. 367-387, 1994.

27. Lichtenthaler, U., Lichtenthaler, E., "A capability-based framework for open innovation: Complementing absorptive capacity", Journal of Management Studies, vol. 46 no. 8, pp. 1315-1338, 2009.

28. Du Plessis, M., "The role of knowledge management in innovation", Journal of Knowledge Management, vol. 11 no. 4, pp. 20-29, 2007.

29. Armstrong, J.S., Overton, T.S., "Estimating nonresponse bias in mail surveys", Journal of Marketing Research, vol. 14 No.3, pp. 396-402, 1977.

30. Huang, H.C., Lai, M.C., Lo, K.W., "Do founders' own resources matter? The influences of business networks on start-up innovation and performance", Technovation, vol. 32 no. 5, pp. 316-327, 2012.

31. Hull, C.E., Covin, J.G., "Learning capability, technological parity, and innovation mode use", Journal of Product Innovation Management, vol. 27 no. 1, pp. 97-114, 2010.

32. Perdomo-Ortiz, J., González-Benito, J., Galende, J., "The intervening effect of business innovation capability on the relationship between total quality management and technological innovation", International Journal of Production Research, 1366588X vol. 47 no. 18 , pp. 5087-5107, 2009.

33. Becheikh, N., Landry, R. and Amara, N., "Lessons from innovation empirical studies in the manufacturing sector: A systematic review of the literature from 1993-2003", Technovation, vol. 26 No.5-6, pp. 644-664, 2006.

34. Chen, M.Y., Chen, A.P., "Knowledge management performance evaluation: A decade review from 1995 to 2004", Journal of Information Science, vol. 32 no. 1, pp. 17-38, 2006.

35. Podsakoff, P.M., Organ, D.W., "Self-reports in organizational research: Problems and prospects", Journal of Management, vol. 12 no. 4, pp. 531-544, 1986.

36. Bentler, P.M., Wu, E.J.C., EAS: Windows user's guide, BMDP Statistical Software, Los Angels, 1993.

37. Aiken, L.S., West, S.G., Multiple regression: Testing and interpreting interactions, Newbury Park, CA: Sage, 1991.

38. Neter, J., Kutner, M.A., Nachtsheim, C.J., Wasserman, W., Applied Linear Statistical Models. Irwin: Chicago, IL, 1996. 